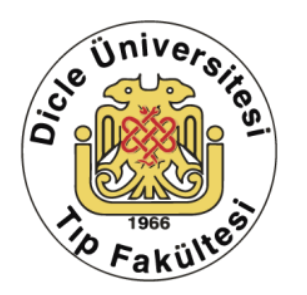

\title{
Alpha-lipoic acid alleviates lipopolysaccharide-induced liver damage in rats via antioxidant effect
}

\author{
Behzat Cimen', Leyla Cimen², Ihsan Cetin ${ }^{3}$, Aysun Cetin ${ }^{4}$ \\ 1 Erciyes University, Faculty of Pharmacy, Department of Biochemistry, Kayseri, Turkey ORCID: 0000-0001-6904-1474 \\ 2 Erciyes University, Faculty of Medicine, Department of Medical Biochemistry, Kayseri, Turkey ORCID: 0000-0002-4730-5595 \\ 3 Hitit University, Faculty of Medicine, Department of Medical Biochemistry, Çorum, Turkey ORCID: 0000-0002-0937-0054 \\ 4 Erciyes University, Faculty of Medicine, Department of Medical Biochemistry, Kayseri, Turkey ORCID: 0000-0003-4959-7955
}

Received: 06.11.2018; Revised: 24.12.2018; Accepted: 04.01.2019

\begin{abstract}
Objective: The effect of lipoic acid (LA), which is considered to be a potential antioxidant, on oxidative stress parameters in liver tissue damage has not been sufficiently investigated. Therefore, we aimed to investigate the relationship of LA with oxidant and antioxidant parameters in lipopolysaccharide (LPS) induced liver damage in rats.

Methods: First group ( $\mathrm{n}=10)$ was injected a single dose of $20 \mathrm{mg} / \mathrm{kg}$ saline (control), second group (n=10) was injected a single dose of $20 \mathrm{mg} / \mathrm{kg}$ LPS (LPS) and third group ( $\mathrm{n}=10)$ was injected a single dose of $20 \mathrm{mg} / \mathrm{kg}$ LPS at the end of third day of $10 \mathrm{mg} / \mathrm{kg} /$ day LA injection (LA+LPS). The glutathione peroxidase (GPX), catalase (CAT) and superoxide dismutase (SOD) activities and the levels of malondialdehyde (MDA) were determined by spectrophotometric method. 3-Nitrotyrosine (3-NT) level was measured by high performance liquid chromatography.

Results: It was found that 3-NT and MDA levels were significantly lower in LA+LPS group than those of LPS group. Moreover, it was found that antioxidant enzyme activity values of LA+LPS approached to the values of control group.

Conclusion: These findings indicate that the oxidant/antioxidant status is balanced in the LA group. Therefore, it may be suggested that LA supplementation to be beneficial for preventing oxidative stress in LPS-induced liver damage in rats.
\end{abstract}

Keywords: Sepsis, liver damage, lipoic acid, natural antioxidant, oxidative stress

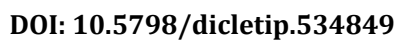

Yazışma Adresi / Correspondence: Ihsan Cetin, Hitit University, Faculty of Medicine, Department of Medical Biochemistry, Çorum, Turkey, e-mail: ihsancetinilim@gmail.com 


\section{Alfa-lipoik asit, antioksidan etkisi ile sıçanlarda lipopolisakkarit kaynaklı karaciğer hasarını azaltır}

\section{Öz}

Amaç: Potansiyel bir antioksidan olarak kabul edilen lipoik asidin (LA), karaciğer doku hasarında oksidatif stres parametreleri üzerindeki etkisi yeterince incelenmemiştir. Bu nedenle, sıçanlarda lipopolisakkaridle (LPS) indüklenen karaciğer hasarında LA'nın oksidan ve antioksidan parametrelerle ilişkisini incelemeyi amaçladık.

Yöntemler: Birinci gruba ( $\mathrm{n}=10), 20 \mathrm{mg} / \mathrm{kg}$ tek doz salin enjekte edildi (kontrol), ikinci gruba ( $\mathrm{n}=10)$, tek doz 20 $\mathrm{mg} / \mathrm{kg}$ LPS enjekte edildi (LPS) ve üçüncü gruba $(\mathrm{n}=10) 3$ gün boyunca enjekte edilen $10 \mathrm{mg} / \mathrm{kg}$ LA sonrasında tek doz $20 \mathrm{mg} / \mathrm{kg}$ LPS enjekte edildi (LA+LPS). Glutatyon peroksidaz (GPX), katalaz (CAT) ve süperoksit dismutaz (SOD) aktiviteleri ve malondialdehid (MDA) düzeyleri spektrofotometrik yöntemle belirlendi. 3-Nitrotirosin (3-NT) seviyesi, yüksek performanslı sıvı kromatografisi ile ölçüldü.

Bulgular: LA+LPS grubunda 3-NT ve MDA düzeylerinin LPS grubuna göre anlamlı derecede düşük olduğu bulundu. Ayrıca, LA+LPS'nin antioksidan enzim aktivite değerlerinin kontrol grubu değerlerine yaklaştığı bulundu.

Sonuç: Bu bulgular, LA grubunda oksidan/antioksidan durumunun dengelendiğini göstermektedir. Bundan dolayl, LA takviyesinin, sıçanlarda LPS kaynaklı karaciğer hasarındaki oksidatif stresi önlemede faydalı olduğu öne sürülebilir.

Anahtar kelimeler: Sepsis, karaciğer hasarı, lipoik asit, doğal antioksidan, oksidatif stress.

\section{INTRODUCTION}

Despite the improvements in monitoring, antibiotic treatment and supportive care, sepsis is the most frequently cause of death in intensive care service ${ }^{1}$. Biochemical mechanism of sepsis advancement are related to the unbalance between activities of antioxidants and reactive oxygen species (ROS) productions ${ }^{2}$. There is excessive production of ROS, while the natural defense mechanisms are diminished the processes implicated in multiple organ failure during sepsis ${ }^{3}$.

Lipopolysaccharide (LPS), is known as the most powerful microbial mediator associated with the pathogenesis of septic shock and sepsis. In response to LPS, macrophages excrete proinflammatory cytokines such as tumour necrosis factor-alpha (TNF- $\alpha$ ) appears to be necessary for most endotoxemic effects, which induce inducible nitric oxide synthase (iNOS) catalyses the nitric oxide (NO). Nitric oxide can further interact with superoxide (02-) to form the peroxynitrite (ONOO-) leading to septic shock with high mortality after a number of mechanisms ${ }^{4}$. The detection of 3-Nitrotyrosine
(3-NT) as a footprint of ONOO- may reflect the degree of ONOO- mediated tissue damage ${ }^{5}$. The relationship between 3-NT and nitrosative tissue damage has also been documented in recent studies using experimental models of endotoxemia ${ }^{6}$.

Natural antioxidants are continually investigated for, such as $\alpha$-lipoic acid (LA), which improves to regulate the oxidationreduction balances ${ }^{7-9}$. Lipoic acid is a disulphide form of octatonic acid; and it has been demonstrated to be useful in obstructing of pathological conditions mediated by inflammation. Additionally, LA is not only water soluble but also lipid and therefore quenches ROS in both lipophilic and hydrophilic mediums $^{8}$. In this case, one of the most healthiest and reliable way is to consume foods containing the natural antioxidant ${ }^{9}$.

Antioxidant supplement has been determined to have protective influences on the treatment of sepsis $^{10}$ and nowadays, antioxidants obtained from natural foods have drawn special attention ${ }^{11}$. Extreme free radicals and lipid peroxidation products cause harms in the 
mitochondria and cell membranes, finally leading to cell necrosis and apoptosis ${ }^{7}$. Previous investigations have revealed that regular intake of LA helps as a protective additive in the prevention of many diseases including diabetes, cardiovascular, neurological systems and diseases caused by viral infections $^{8}$. It has been showed that LA effectively attenuated LPS-induced acute inflammatory response in lung tissues in a cecal ligation and LPS-induced sepsis ${ }^{12}$. Although intense struggles, the effect mechanisms of LA on sepsis remain poorly understood. Previous studies showed that LA treatment increased superoxide dismutase (SOD) and catalase (CAT) activities, and decreased levels of malondialdehyde (MDA) in liver and kidney ${ }^{13}$. According to our literature knowledge, there are no studies having investigated relationship of LA with 3-NT and glutathione peroxidase (GPX) in LPS induced liver sepsis although there are some studies about the effect of LA treatment on liver of rats with different sepsis models. Therefore, we aimed to investigate whether LA has an effect on MDA, 3-NT, SOD, CAT and GPX in LPS-induced liver damage in rats.

\section{METHODS}

\section{Experimental Design}

The experimental procedures performed in this study were reviewed and confirmed by the xxxxxx University Ethics Committee of Experimental Animals (5-08/25-09.04.2008). The experiments procedures were performed on 30 adult male wistar rats with the weights changing between 260-310 g. The rats were nestled under standard circumstances, a 12/12 h dark-light cycle (light on at 19:00 p.m.), humidity of $55 \pm 5 \%$ and an ambient temperature of $20 \pm 2^{\circ} \mathrm{C}$. The rats were fed with a standard food and water. The rats were randomly separated into three clusters. Control group injected intraperitoneal (IP) single dose of saline $(n=10)$. These rats were sacrificed under xylazine/ketamine anaesthesia and liver tissues were taken at 6th hour after saline injections. LPS group injected IP single dose of $20 \mathrm{mg} / \mathrm{kg}$ LPS $(\mathrm{n}=10) 4$. Later, the rats were sacrificed under xylazine/ketamine anaesthesia and liver tissues were taken at 6th hour after injections of LPS4. LA+LPS group $(n=10)$ received IP single dose of $20 \mathrm{mg} / \mathrm{kg}$ LPS at the end of third day of injection $10 \mathrm{mg} / \mathrm{kg} /$ day LA5. Later, these rats also were sacrificed under xylazine/ketamine anaesthesia and liver tissues were taken at 6th hour after injections of LPS ${ }^{13}$.

\section{Biochemical Analysis}

Protein concentrations in liver were measured via spectrophotometric assay with bovine serum albumin protein as usual ${ }^{14}$.

\section{Determination of MDA levels}

The liver MDA levels were determined by reaction between MDA and thiobarbituric acid15. The liver tissues were homogenized in

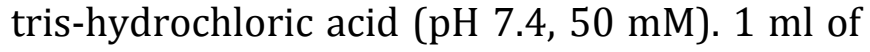
liver homogenate was added to $1.5 \mathrm{ml}$ of thiobarbituric acid ( $0.8 \%)$. Then $1.5 \mathrm{ml}$ of acetic acid and $0.4 \mathrm{ml}$ of sodium dodecyl (8.1\%) sulphate were added into the above solution. The solution was completed $5 \mathrm{ml}$ with pure water and placed in water bath for 60 minute at $96^{\circ} \mathrm{oC} .5 \mathrm{ml}$ of the mixture of pyridine and $\mathrm{n}$ butanol (1:15, v/v) were added and centrifugated for $10 \mathrm{~min}$ at $4000 \mathrm{rpm}$, the final solution was vortexed and, the density of the upper layer was determined at $532 \mathrm{~nm}$ by the spectrophotometer. The results were demonstrated as $\mathrm{nmol} / \mathrm{g}$ tissue.

\section{Measurement of 3-Nitrotyrosine}

The liver nitrotyrosine levels were determined by High Performance Liquid Chromatography (HPLC) technique implemented by Cimen et al.16 briefly as follows: $0.3 \mathrm{ml}$ of serum specimen was taken for this operation to precipitate protein, an addition of $0.3 \mathrm{ml}$ of $10 \%$ TCA on serum specimen. After 
centrifugating for $10 \mathrm{~min}$ at $3000 \mathrm{rpm}$, samples hydrolyzed at $100{ }^{\circ} \mathrm{C}$ for $18-24 \mathrm{~h}$ in $6 \mathrm{~N} \mathrm{HCl}$. The samples were determined on a diode array detector (Hewlett Packard, Germany) ${ }^{4,17}$.

\section{Determination of CAT activity}

The liver tissues were homogenized in phosphate tampon (50 mM, pH 7.4) ratio of $1 / 10 \quad(\mathrm{v} / \mathrm{v})$. Then homogenates were centrifuged at $4^{\circ} \mathrm{C}$ and $15000 \mathrm{xg}$ for 15 minute. Determinations of CAT activities were made in supernatant obtained. CAT activities were determined by the method which makes use of advantage of the peroxidatic activities of catalase18. In phosphate buffered environment, the disintegration of $\mathrm{H} 2 \mathrm{O} 2$ by the effect of catalase of the sample causes a decrease 240 $\mathrm{nm}$ in absorbance. The findings were demonstrated as k/g-protein.

\section{Determination of GPx activity}

The liver tissues were homogenized by phosphate buffer $(50 \mathrm{mM}, \mathrm{pH} \quad 7.5$ and containing $0.5 \mathrm{mM}$ EDTA). Then homogenates were centrifuged at $4{ }^{\circ} \mathrm{C}$ and $12000 \mathrm{xg}$ for 15 minutes. Determination of GPx activities were made in supernatant obtained after centrifugation. The activities of GPx were measured using the method developed by Paglia et al.19. The activities of GPx were determined using the slope of these lines as $\mu$ moles of NADPH oxidized per min at $340 \mathrm{~nm}$ absorbance for $5 \mathrm{~min}(6.22 \times 103 \mathrm{M}-1 . \mathrm{cm}-1)$. The results were expressed as U/g protein.

\section{Determination of SOD activity}

The homogenized liver tissues mixed with methanol/chloroform mixture ratio of $1 / 1$ $(\mathrm{v} / \mathrm{v})$, then centrifuged at 5,000xg for 2 hours at $4^{\circ} \mathrm{C}$. Determination of SOD activities were made in supernatant obtained after centrifugation. SOD activities were determined by the proposed method by Sun et al.20. The guideline of this technique is based upon the inhibition of nitroblue tetrazolium reduction and formation of blue formazan which has absorbance at $560 \mathrm{~nm}$. In addition, SOD activity was pointed out as units per millilitre for liver measurements and the findings were stated as $\mathrm{U} / \mathrm{mg}$ protein.

\section{Statistical Analysis}

SPSS software version 15.0 and SigmaStat 3.5 statistics programs were used for statistical analyses (IBM Corp., New York, USA). Kolmogorov-Smirnov test was used for normality of data distribution. Student's $t$ test was used for the values match a normal distribution. The data did not match a normal distribution, which was conducted with the help of Mann-Whitney $U$ tests. The data of statistics for normal distribution were given as mean \pm standart deviation. Statistical significance was set at 0.05 .

\section{RESULTS}

The liver tissue levels of oxidative stress and antioxidant parameters in rats are shown in Table 1 . The levels of MDA were significantly higher $(116.2 \pm 2.11)$ in the LPS group compared with those of the controls $(77.4 \pm 8.46)$ and the LA+LPS $(107.2 \pm 4.28)$ groups. The levels of MDA were significantly higher in the LA+LPS than those of controls (Figure 1). The levels of 3 -NT were significantly higher $(4.01 \pm 0.07)$ in the LPS group than those of the LA+LPS $(1.03 \pm 0.06)$ group. It was not determined 3-NT levels in control group (Figure 2; Table 1).

The activities of CAT were significantly lower (32.3 \pm 4.25$)$ in the LPS group than those of the control (46.4 \pm 4.98$)$ and the $(40.96 \pm 3.99)$ LA+LPS groups. However, The activities of CAT were significantly lower in the LA+LPS groups than those of the control group (Figure 3). The GPx activities were significantly lower $(8.18 \pm 0.29)$ in the LPS group than those of the control $(9.5 \pm 0.36)$ and the LA+LPS groups (9.13 \pm 0.10$)$. Similarly, SOD activities were significantly lower $(0.11 \pm 0.006)$ in the LPS group than those of the control $(0.14 \pm 0.001)$ and the LA+LPS groups $(0.13 \pm 0.002)$. However, 
the activities of GPx and SOD were significantly lower in the LA+LPS groups than those of the control group (Figure 3).
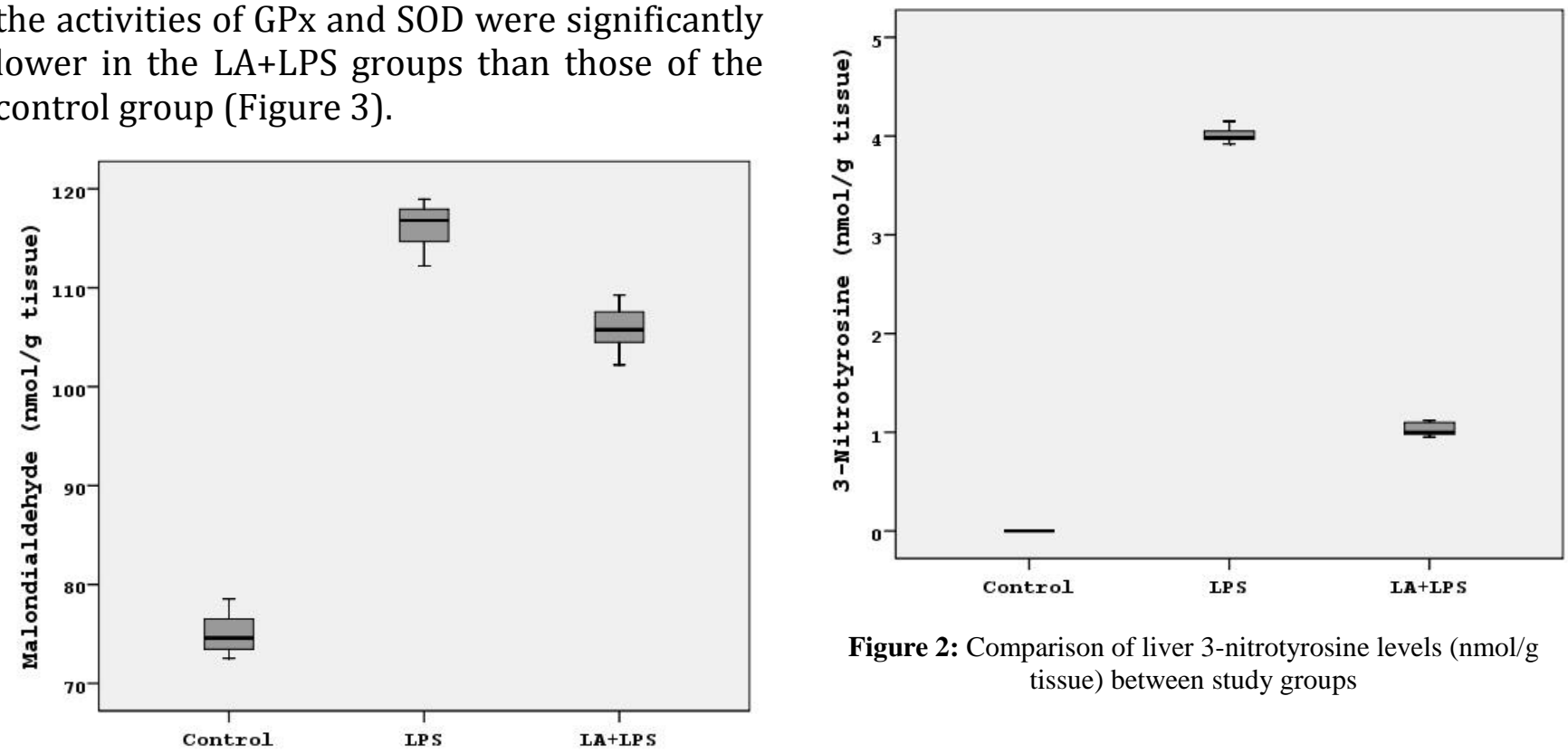

Figure 2: Comparison of liver 3-nitrotyrosine levels (nmol/g tissue) between study groups

Figure 1: Comparison of liver malondialdehyde levels (nmol/g tissue) between study Groups

Table 1: Oxidant/antioxidant parameters levels of liver tissue in rats.

\begin{tabular}{|ccccccc|}
\hline & \multicolumn{3}{c}{ Groups } & \multicolumn{3}{c|}{ Comparisons } \\
\cline { 2 - 7 } Parameters & $\begin{array}{c}\text { Controls } \\
(n=10)\end{array}$ & $\begin{array}{c}\text { LPS } \\
(n=10)\end{array}$ & $\begin{array}{c}\text { LA+LPS } \\
(n=10)\end{array}$ & $\begin{array}{c}\text { LPS } \\
\text { Controls } \\
\boldsymbol{p}\end{array}$ & $\begin{array}{c}\text { LA+LPS } \\
\text { Controls } \\
\boldsymbol{p}\end{array}$ & $\begin{array}{c}\text { LPS } \\
\text { LAPS } \\
\boldsymbol{p}\end{array}$ \\
\hline MDA (nmol/g tissue) & $77.4 \pm 8.46$ & $116.2 \pm 2.11$ & $107.2 \pm 4.28$ & $<0.001$ & $<0.001$ & $<0.001$ \\
3-NT (nmol/g tissue) & - & $4.01 \pm 0.07$ & $1.03 \pm 0.06$ & - & - & $<0.001$ \\
CAT (k/g protein) & $46.4 \pm 4.98$ & $32.3 \pm 4.25$ & $40.96 \pm 3.99$ & $<0.001$ & 0.017 & $<0.001$ \\
GPx (U/g protein) & $9.5 \pm 0.36$ & $8.18 \pm 0.29$ & $9.13 \pm 0.10$ & $<0.001$ & 0.008 & $<0.001$ \\
SOD (U/mg protein) & $0.14 \pm 0.001$ & $0.11 \pm 0.006$ & $0.13 \pm 0.002$ & $<0.001$ & $<0.001$ & $<0.001$ \\
\hline
\end{tabular}

Data are expressed as mean \pm SD for continuous variables. $n=10$ in each group. MDA: Malondialdehyde, 3-NT: 3-Nitrotyrosine, CAT: Catalase, GPX: Glutathione peroxidase, SOD: Superoxide dismutase.

\section{DISCUSSION}

Our findings present evidence for beneficial effect of LA on liver tissues in sepsis as shown by liver levels of MDA and 3-NT, statistically significant lower in LA+LPS than those of LPS group. On the other hand, we found that liver activities of GPx, CAT and SOD were significantly higher in LA+LPS than those of LPS group.
In the mechanism of LPS-induced cellular degeneration, the increased production of reactive nitrogen species is put forwarded as triggering factors ${ }^{20}$. A number of investigations have suggested that NO is composed in extreme levels as a result of iNOS stimulation by LPS or cytokines leading to prevention in DNA damage, apoptosis and mitochondrial energy metabolism in hepatocyte ${ }^{21}$. Previously, some groups have reported that iNOS induction 
reaches a maximum level at 6th hour after the LPS injection and falls sharply after 12 hours and almost returns to unmeasurable concentrations after 24 hours ${ }^{4,17,22}$. So, we measured levels of oxidative stress and antioxidant enzymes activities of liver at 6 th hour after LPS injection. In our study, liver levels of 3-NT and MDA were significantly higher in the LPS group than those of the LA+LPS and control groups.

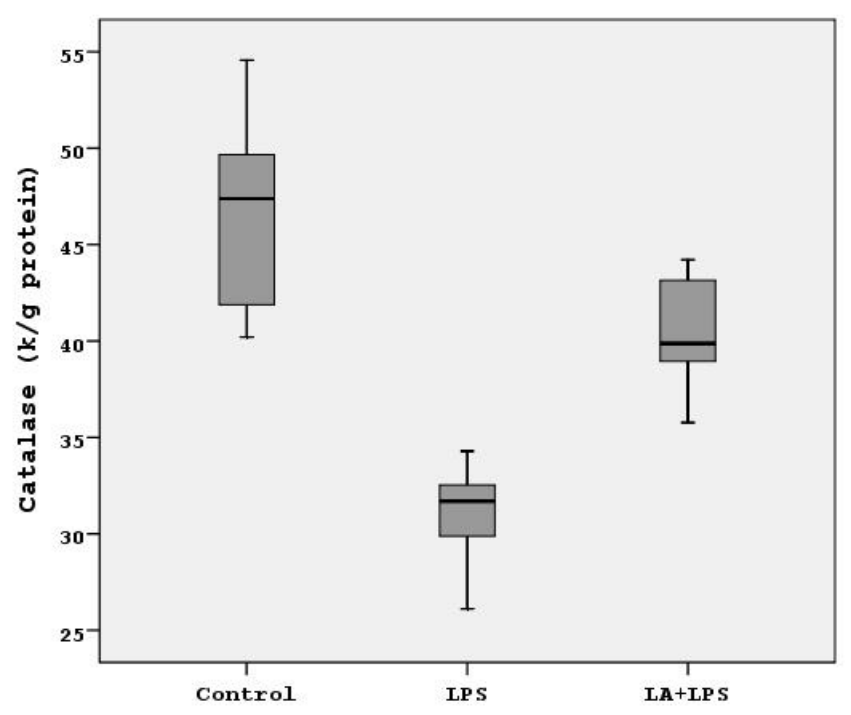

Figure 3: Comparison of liver catalase levels (k/g protein) activities between study groups

Enhanced lipid peroxidation products levels are found in rats with sepsis ${ }^{23}$, and tissue levels of MDA are increased in rats with LPS induced septic shock ${ }^{24}$. Petronilho et al. showed that LA was influential in decreasing activity of myeloperoxidase, liver lipid peroxidation and protein carboxylation in kidney after cecal ligation puncture. Patients with septic shock have also enhanced MDA levels of plasma ${ }^{25}$. The evaluation of ONOO- induced tissue damage can be monitored by determination 3NT in different ways because of the status that ONOO- has a very short-lived expectancy26. 3NT was measured with immunostaining experiments, but they detected no labelling of
iNOS and 3-NT in histologically normal liver tissues $^{10}$.

We have previously shown that LPS deteriorates membrane $\mathrm{Na}+, \mathrm{K}+$ ATPase activity in guinea pigs ${ }^{16}$. Moreover, there are studies finding a important hepatocellular excretion of iNOS in all liver specimens from patients with liver disease. It has been shown that melatonin inhibits the formation of NO by inhibiting iNOS and maintains ATP stores via preserving the respiratory chain in rat liver ischemiareperfusion model ${ }^{27}$. It also has been found that iNOS activities have decreased in a dosedependent manner, and it has improved ONOOmediated mitochondrial respiratory chain after the treatment with melatonin.

In other LPS induced animal models of chronic and acute inflammation, it was advocated that melatonin has anti-inflammatory effect. In this aspect, our results are consistent with previous studies. It is known that NO and cytotoxic reactive nitrogen species formed from NO and 02- account for cellular damage and dysfunction associated with LPS-mediated liver inflammation ${ }^{28}$. It may be suggested that the ONOO- failure, which may occur as a result of inhibition of iNOS by LA, may prevent the formation of 3-NT as in our study.

The second most important finding of our study is the demonstration of the protective effect of LA on antioxidant power in liver of rats with sepsis. In our study, LPS caused a substantial decline in GPx, CAT and SOD activities of liver tissues than those of the LA+LPS and control group. More important, we found that LA application increased the CAT, GPx and SOD activities in liver tissues of LA+LPS groups than those of LPS group.

Previous investigations have showed that LA supplementation restoring has diminished levels of the antioxidants while decreased levels of oxidative stress parameters ${ }^{25}$. It has been are reported that patients with sepsis have lower antioxidant levels ${ }^{10}$. SOD 
transforms 02 - into $\mathrm{H} 2 \mathrm{O} 2$, which is the target molecule of GPx and CAT. CAT being the most significant peroxidase in the organs studied in this work ${ }^{29}$. Indeed, Petronilho et al. showed that sepsis incited a propensity to reduce activities of SOD and CAT after cecal ligation puncture in liver, which were reversed via LA supplementation $^{25}$. However, in $24 \mathrm{~h}$, it was influential in decreasing activities of CAT and SOD in several organs but it was not reversed with LA treatment. It was found that the most powerful and considerable changes in the activity of GSH. However, the effects of lipoic acid on GPx activity of liver in sepsis were not examined in the study conducted by Petronilho et al.25. Considering this aspect, we can suggest that our study has completed the missing piece of the puzzle. In addition to the findings of Petronilho et al.25, we found that LPS-induced liver damage in rats showed not only SOD and CAT activities but also GPx activity in lipopolysaccharide-induced liver damage in rats.

Previous researches demonstrated that LA reduced singlet oxygen and hydroxyl radicals ${ }^{30}$. The improvement of oxidative damage severity and the anti-oxidative power by LA in 6th after LPS may be indicative that it can decompose 02- and H2O2. Taken these results together, we may suggest that sepsis have deteriorated oxidant/antioxidant balance because of the increased liver levels of 3-NT and MDA and reduced GPX, CAT and SOD activities.

\section{CONCLUSIONS}

In conclusion, our results confirmed the suggestion that LA diminished oxidative damage induced with sepsis in liver by its antioxidative capacity. Inability of iNOS activity, which, as a result of the elimination of the 02 radical, increased antioxidant activity resulting in failure to form the ONOO. Nevertheless, liver damages induced with LPS have not returned perfectly to control levels in terms of GPx, CAT and SOD activities as well as the MDA and 3- NT in liver with initially given LA dose (10 $\mathrm{mg} / \mathrm{kg} /$ day). Therefore, future investigations may be needed to prevent the tissue damage and the given LA dose should be regulated.

Declaration of Conflicting Interest: The authors have no competing interests

Financial Disclosure: This research was conducted within the scope of the project (TSA08-590) which was funded by Erciyes University Scientific Research Projects Unit

\section{REFERENCES}

1. Erenler AK, Yapar D, Terzi Ö. Comparison of Procalcitonin and C-reactive Protein in Differential Diagnosis of Sepsis and Severe Sepsis in Emergency Department. Dicle Med J. 2017; 44: 175-82.

2. Ekinci A. Investigation of serum oxidative stress levels in patients with nasal polyps. Dicle Med J. 2018; 45: 1-7

3. Oluwole OG, Ologe O, Alabi A, Tunde YG, Umukoro S. Anti-inflammatory effects and anti-oxidant capacity of Myrathius arboreus (Cecropiaceae) in experimental models. J Basic Clin Physiol Pharmacol. 2017; 28: 5219.

4. Islam BU, Habib S, Ali SA, Moinuddin, Ali A. Role of Peroxynitrite-Induced Activation of Poly(ADP-Ribose) Polymerase (PARP) in Circulatory Shock and Related Pathological Conditions. Cardiovasc. Toxicol. 2017; 17: 373-83.

5. Ahsan H. 3-Nitrotyrosine: A biomarker of nitrogen free radical species modified proteins in systemic autoimmunogenic conditions. Hum Immunol. 2013; 74: 1392-9.

6. Kurutas EB. The importance of antioxidants which play the role in cellular response against oxidative/nitrosative stress: current state. Nutr J. 2016; 15: 71.

7. Huk-Kolega HB, Skibska P, Kleniewska A, Piechota Ł, Michalski AG. "Rola kwasu liponowego w zdrowiu ichorobie," Polski Merkuriusz Lekarski. 2011; 31: 1835.

8. Ozgun E, Ozgun GS, Usta U, et al. The effect of lipoic acid in the prevention of myocardial infarction in diabetic rats. Bratisl Lek Listy. 2018; 119: 664-9.

9. Baranowska M, Bartoszek A. Antioxidant and antimicrobial properties of bioactive phytochemicals from cranberry. Postepy Hig Med Dosw. 2016; 70: 1460-8. 
10. Prauchner CA, Prestes Ade S, da Rocha JB. Effects of diphenyl diselenide on oxidative stress induced by sepsis in rats. Pathol Res Pract. 2011; 207: 554-8.

11. Li X, Wang L, Han W, et al. Amentoflavone protects against hydroxyl radical-induced DNA damage via antioxidant mechanism. Turk J Biochem. 2014; 39: 3036.

12. Güzel EE, Kaya N, Kocamüftüoğlu GO, et al. Investigation of the Effects of Alpfa Lipoic Acid on Changes in Maternal Rat Lung Caused by Tobacco Smoke Exposure in Pregnancy Dicle Med J. 2018; 45: 297-307.

13. Zalejska-Fiolka J, Wielkoszyński T, Kasperczyk S, Kasperczyk A, Birkner E. Effects of oxidized cooking oil and $\alpha$-lipoic acid on liver antioxidants: enzyme activities and lipid peroxidation in rats fed a high fat diet. Biol Trace Elem Res. 2010; 138: 272-81.

14. Lowry $\mathrm{OH}$, Rosebrough NJ, Farr AL, Randall RJ. Protein measurement with the Folin phenol reagent. J Biol Chem. 1951; 193: 265-75.

15. Ohkawa H, Ohishi N, Yagi K. Assay for lipid peroxides in animal tissues by thiobarbituric acid reaction. Anal Biochem. 1979; 95: 351-8.

16. Cimen B, Türközkan N, Seven I, Unlü A, Karasu C. Impaired $\mathrm{Na}+\mathrm{K}+$-ATPase activity as a mechanism of reactive nitrogen species-induced cytotoxicity in guinea pig liver exposed to lipopolysaccharides. Mol Cell Biochem. 2004; 259: 53-7.

17. Liu S, Adcock IM, Old RW, Barnes PJ, Evans TW. Lipopolysaccharide treatment in vivo induces widespread tissue expression of inducible nitric oxide synthase mRNA. Biochem Biophys Res Commun. 1993; 196: 1208-13.

18. Yasmineh WG, Kaur TP, Blazar BR, Theologides A. Serum catalase as marker of graft-vs-host disease in allogeneic bone marrow transplant recipients: pilot study. Clin Chem. 1995; 41: 1574-80.

19. Paglia DE, Valentine WN. Studies on the quantitative and qualitative characterization of erythrocyte glutathione peroxidase. J Lab Clin Med. 1967; 70: 15869.

20. Sun Y, Oberley LW, Li Y. A simple method for clinical assay of superoxide dismutase. Clin Chem. 1988; 34: 497-500.
21. de S Moreira D, Figueiró PW, Siebert C, et al. Chronic Mild Hyperhomocysteinemia Alters Inflammatory and Oxidative/Nitrative Status and Causes Protein/DNA Damage, as well as Ultrastructural Changes in Cerebral Cortex: Is Acetylsalicylic Acid Neuroprotective? Neurotox Res. 2018; 33: 580-92.

22. Bharrhan S, Chopra K, Arora SK, Toor JS, Rishi P. Down-regulation of NF- $\kappa B$ signalling by polyphenolic compounds prevents endotoxin-induced liver injury in a rat model. Innate Immun. 2012; 18: 70-9.

23. Petronilho F, Florentino D, Danielski LG, et al. AlphaLipoic Acid Attenuates Oxidative Damage in Organs After Sepsis. Inflammation. 2016; 39: 357-65.

24. El-Awady MS, Nader MA, Sharawy MH. The inhibition of inducible nitric oxide synthase and oxidative stress by agmatine attenuates vascular dysfunction in rat acute endotoxemic model. Environ Toxicol Pharmacol. 2017; 55: 74-80.

25. Petronilho F, Florentino D, Danielski LG, et al. AlphaLipoic Acid Attenuates Oxidative Damage in Organs After Sepsis. Inflammation. 2016; 39: 357-65.

26. Zhang HX, Liu SJ, Tang XL, et al. H2S Attenuates LPSInduced Acute Lung Injury by Reducing Oxidative/Nitrative Stress and Inflammation. Cell Physiol Biochem. 2016; 40: 1603-12.

27. Paradies G, Paradies V, Ruggiero FM, Petrosillo G. Protective role of melatonin in mitochondrial dysfunction and related disorders. Arch Toxicol. 2015; 89: 923-39.

28. Choi YJ, Kim HS, Lee J, et al. Down-regulation of oxidative stress and COX-2 and iNOS expressions by dimethyl lithospermate in aged rat kidney. Arch Pharm Res. 2014; 37: 1032-8.

29. Sadi G, Kartal Dİ, Güray T. Regulation of Glutathione S-Transferase Mu with type 1. Turk J Biochem. 2013; 38; 92-100.

30. Safa J, Ardalan MR, Rezazadehsaatlou M, et al. Effects of alpha lipoic acid supplementation on serum levels of IL-8 and TNF- $\alpha$ in patient with ESRD undergoing hemodialysis. Int Urol Nephrol. 2014; 46: 1633-8. 